\title{
EL CONTROL ECONÓMICO-FINANCIERO EXTERNO DEL ESTADO: EL TRIBUNAL DEL CUENTAS
}

\author{
YOLANDA GÓMEZ SÁNCHEZ \\ Profesora Titular de Derecho Constitucional \\ UNED
}





\title{
EL CONTROL ECONÓMICO-FINANCIERO EXTERNO DEL ESTADO: EL TRIBUNAL DE CUENTAS
}

\author{
POR \\ YOLANDA GÓMEZ SÁNCHEZ \\ Profesora Titular de Derecho Constitucional \\ UNED
}

SIGLARIO

\begin{abstract}
AA . Actualidad Administrativa
$\mathrm{AAz} \quad$ Actualidad Aranzadi

AHDE Anuario de Historia del Derecho Español

BICAM Boletín del llustre Colegio de Abogados de Madrid

BIMJ Boletín de Información del Ministerio de Justicia

BOE Boletín Oficial del Estado

HPE Hacienda Pública Española

IEAL Instituto de Estudios de Administración Local

IEF Instituto de Estudios Fiscales

PGP Presupuesto y Gasto Público

PPU Promociones y Publicaciones Universarias

RAP Revista de Administración Pública

RDFHP Revista de Derecho Financiero y Hacienda Pública

RDJ Revista de Derecho Judicial

RDP Revista de Derecho Político

REDA Revista Española de Derecho Administrativo.

REDF Revista Española de Derecho Financiero

RGLJ Revista General de Legislación y Jurisprudencia

TCu Tribunal de Cuentas
\end{abstract}




\section{OBRAS DE CARÁCTER GENERAL}

Albiñana, C.: Sistema Tributario Español y Comparado, 2ª ed. Tecnos, Madrid, 1986.

Ferreiro Lapatza, J. J.: Curso de Derecho Financiero Español, M. Pons, Madrid 1990.

Martín Queralt, J. y Lozano Serrano, C.: Curso de Derecho Financieto y Tributario, Tecnos, Madrid, 1990.

Moreno Catena, V.: Derecho Procesal, Tomo I (Vol. II), Proceso Civil (2), Valencia, 1987, pág. 62.

Palao Taboada: Derecho Financiero y Tributario, vol. 1, Madrid, 1987, pág. 162.

SÁinz de Bujanda, F.: Lecciones de Derecho Financiero, Servicio de Publicaciones Facultad de Derecho, Universidad Complutense, Madrid, 1979.

Schwab, W.: Presupuesto público y contabilidad, Viena, 1976.

Torres del Moral, A.: Principios de Derecho Constitucional Español, vol. 2, Servicio de Publicaciones Facultad de Derecho, Universidad Complutense, Madrid, 1991.

VV.AA.: Estudios sobre la Constitución Española. (Homenaje al Prof. Eduardo García de Enterría). Tomos IV y V, Civitas, Madrid, 1991.

II. EL CONTROL ECONÓMICO-FINANCIERO Y ORIGEN DEL TRIBUNAL DE CUENTAS

Albiñana García-Quintana, C.: El control de la Hacienda Pública en España, en FABRE/ALBIÑANA, «El control de la Hacienda Pública», Rialp, Madrid, 1971.

Aragón Reyes, M.: El control parlamentario como control político, $R D P, n^{\circ}$ 23 (1983), pág. 95 y ss.

Aragón Sánchez: Presupuestos del Estado, Cuenta General y Tribunal de Cuentas, vol. 1, IEF, Madrid, 1987.

- Hacia un modelo simplificado de contabilidad, Tribunal de Cuentas, Madrid, 1994. 
Artola, M.: La Hacienda del Antiguo Régimen, Madrid, 1982.

Asenjo Martinez: La privatización de la empresa pública, Tribunal de Cuentas, Madrid, 1994.

Barriobero y Armas, J.: España (Leyes de Hacienda Pública), Librería Internacional de Romo, Madrid, 1935.

BermeJo, J. L.: "Superintendencias en la Hacienda del Antiguo Régimen", A.H.D.E., 54, (1984).

BurLAUD, A.: El control de la gestión de los servicios públicos, P.G.P., no 4, (1979), pág. 318.

Canga Argüelles, J.: voz: Superintendente General del Diccionario de Hacienda, ed. facsimil del I.E.F., Madrid, 1961.

CARANDE, R.: Carlos $V$ y sus banqueros, 3 vols. II "La Hacienda Real de Castilla", Madrid, 1949.

Del Moral, J.: Hacienda y sociedad en el trienio constitucional, 1820-1823, Madrid, 1975.

Desdevises su Dezert, G.: La España del Antiguo Régimen, ed. facsimil, Madrid, 1989.

Fabre, F. J.: El Control de la Hacienda Pública, Madrid, 1971.

Fernández-Victorio Camps, S.: El Tribunal de Cuentas en las Constituciones españolas, P.G.P., no 3 (1979), págs. 79 y ss.

Fernández Pirla, J. Ma y Sala Sánchez, P.: El Tribunal de Cuentas, ayer y hoy, Tribunal de Cuentas, Madrid, 1987.

FontANA, J.: Hacienda y Estado en la crisis final del Antiguo Régimen. 18231833, Madrid, 1973.

- La Hacienda en la Historia de España. 1700-1931, Madrid, 1980.

FucHS, A.: Wesen und wirken der kontrolle, Mohr, Tübingen, 1966.

Gallardo, F.: Origen, proceso y estado de las rentas de la Corona en España, su gobierno y su administración, Madrid, 1805.

Garcia-Trevijano, J. A.: "La nueva Ley Orgánica del Tribunal de Cuentas», R.E.D.A., no 12, (1953). 
Garzón Pareja, M.: Historia de la Hacienda de España, 2 vols., Madrid, 1984.

Gibert y Sánchez de la Vega, R.: «Contadores de Hacienda e intervención fiscal en el Antiguo Régimen castellano" en Itinerario histórico de la Intervención General de la Administración del Estado, I.E.F., Madrid, 1976 , págs. 87 y ss.

- El Tribunal Mayor de Cuentas de Fernando VII, Tribunal de Cuentas, Madrid, 1986.

González Cedrón, A.; Méndez de Vigo, L. y Emilio Peral, F.: Nociones Generales de Contabilidad Pública, Madrid, 1900.

KUCHLER, W.: Die Finanzen der Frone Aragón während des 15. Jahrshunderts (Alfons V. und Johann II), Münster, 1983.

Ladero, M. A.: La Hacienda Real de Castilla en el siglo XV, La Laguna, 1973.

LASARTE, J.: Economía y Hacienda al final del Antiguo Régimen, Madrid, 1976.

López Rodo, L.: La Administración Pública y las transformaciones socioeconómicas, Madrid, 1963.

Martín Niño, J.: La Hacienda española y la revolución de 1868, Madrid, 1972.

Mendizabal Allende, R.: "Función y esencia del Tribunal de Cuentas", R.A.P., no 46 (enero/abril, 1965), pág. 13.

- "La Contaduría Mayor de Cuentas, R.D.J., n²5, (1966), págs. 11 y ss.

- «El Tribunal de Cuentas y el nacimiento de la Administración contemporánea", R.A.P., no 49, (1966), págs. 101 y ss.

- "La crisis del "Antiguo Régimen" y la jurisdicción contable», R.G.L.J., tomo LIV, no 222, (1967), págs. 12 y ss.

- "La Revolución de 1968 y el Tribunal de Cuentas", R.D.F.H.P., no 74, (1968), págs. 301 y ss.

- «El Tribunal Supremo de la Hacienda Pública», R.A.P., no 56, (1968), págs. 123 y ss.

MonTAgUt, T.: El Maestro Racional en la Corona de Aragón (1283-1419), Tesis Doctoral, Universidad de Barcelona, 1982. 
Ortiz ArCe, D.: "Tribunal de Cuentas del Reino", Enciclopedia Jurídica Seix, vol. XXX, págs. 383 y ss.

Pérez Bustamante, R.: "Del sistema de contadurías al Consejo de Hacienda, 1433-1525 (una perspectiva institucional)", en Historia de la Hacienda Española (Epocas Antigua y Medieval), Madrid, 1982.

Piernas Hurtado, J. M.: Tratado de Hacienda Pública y examen de la española, Madrid, 1881.

QuintANA LóPEZ, T.: "El Tribunal de Cuentas y la teoría estatutaria del Derecho administrativo", R.A.P., no 116, (mayo-agosto, 1988), págs. 173 y ss.

Raquejo Alonso, A.: «Estudio sobre la fiscalización previa», H.E.P., no 31, (1974), págs. 105 y ss.

RosIÑOL I VIDAL: La responsabilidad contable y la gestión de los recursos públicos: análisis de la doctrina del Tribunal de Cuentas, Madrid, 1994.

SALCEDo lzU, J.: El sistema fiscal navarro en la Cámara de Comptos Reales, ed. Príncipe de Viana, 163 (Mayo-agosto), 1981.

TomÁs y VALIENTE, F.: Presentación a la Colección de las Leyes, Ordenanzas, Plantas, Decretos, Instrucciones y Reglamentos expedidos para el Gobierno del Tribunal y Constaduría Mayor de Cuentas desde el reinado del Señor don Juan Il hasta el día, Imprenta Real, Madrid, 1829.

Torres Sanz, D.: La Administración Central castellana en la Baja Edad Media, Valladolid, 1982.

UltoA, M.: La Hacienda Real de Castilla en el reinado de Felipe II, Madrid, 1977.

Zabalo, J.: La Administración del Reino de Navarra en el siglo XIV, Pamplona 1973.

III. EL TRIBUNAL DE CUENTAS COMO INSTITUCIÓN DE CONTROL ECONÓMICO-FINANCIERO: FUNCIONES, COMPOSICIÓN Y RELACIONES CON LAS CORTES GENERALES

Agundez Fernández, A.: "Naturaleza jurisdiccional del Tribunal de Cuentas, en El Tribunal de Cuentas en España, vol. I, IEF, Madrid, 1982, págs. 195 y ss. 
Agundez Fernández, A. y otros: "El Tribunal de Cuentas en Españan, Congreso de la Dirección General de lo Contencioso del Estado, I.E.F., Madrid, 1992.

Albiñana Garcia-Quintana, C.: "Ambito subjetivo del control a efectuar por el Tribunal de Cuentas», en El Tribunal de Cuentas. Crónica, 1981, Madrid, 1982.

- "La función fiscalizadora del Tribunal de Cuentas", en El Tribunal de Cuentas en España, vol. I, I.E.F., Madrid, 1982, págs. 35 y ss.

- "La pretendida jurisdicción del Tribunal de Cuentas", P.G.P., no 17 (1983), págs. 9 y ss.

- "Artículo 31. El gasto público», en Comentarios a las Leyes Políticas. Constitución Española de 1978, Tomo III, Madrid, 1983.

- «Revisión del procedimiento de fiscalización del Tribunal de Cuentas por la jurisdicción contencioso-administrativa», P.G.P., no 26 (1985), págs. 141 y ss.

Algibez Cortés, J. L.: "La pieza separada como actuación previa a la exigencia de responsabilidades contables por el Tribunal de Cuentas", en Tribunal de Cuentas. Crónica, 1988-1989, Tribunal de Cuentas, Madrid, 1990, págs. 225 y ss.

Álvarez Bonald, M.: “¿Será suficiente el desarrollo orgánico-constitucional para una auténtica función del Tribunal de Cuentas?", en: Control del sector público, IEF, Madrid, 1981.

Álvarez Bonald, M. Y Martín Martín, P.: "Las relaciones entre la jurisdicción penal y la jurisdicción contable. Cuestiones prejudiciales", en Jornadas conmemorativas del décimo aniversario de la aprobación de la Ley Orgánica del Tribunal de Cuentas, de 12 de mayo de 1982, Madrid, 1986

Aragón Reyes, M.: "El control parlamentario como control político", R.D.P., nํ 23, (1986), pág. 12.

Aragón SánChez, C.: "El Tribunal de Cuentas y la Intervención General en la Administración del Estado en el control de la gestión económica del sector público", en Control del sector Público, I.E.F., Madrid, 1981, págs. 413 y ss.

- "Presupuesto del Estado, Cortes Generales y Tribunal de Cuentas", P.G.P., n으 25 (1985), págs. 9 y ss. 
- "El Tribunal de Cuentas y la Administración Local», en Tribunal de Cuentas, Crónica, 1980, Madrid, 1981, págs. 241 y ss.

- "Presupuestos del Estado, Cortes Generales y Tribunal de Cuentas", P.G.P., no 25, (1985).

- "Las responsabilidades contables en la Ley General Presupuestaria y en la Ley Orgánica del Tribunal de Cuentas", en Tribunal de Cuentas, Crónica, 1987. Tribunal de Cuentas, Madrid, 1988, págs. 1 y ss.

Arnedo Orbañanos, M. A.: "La posición del Consejero Ponente en las actuaciones previas a la exigencia de responsabilidades contables no constitutivas de alcance", en Crónica 1992-1993, Tribunal de Cuentas, Madrid, 1994.

Asenjo Martinez, S. E.: "El Tribunal de Cuentas y las sociedades estatales», en Tribunal de Cuentas, Crónica, 1980. Tribunal de Cuentas, Madrid, 1981 , págs. 478 y ss.

- "La administración interna del Tribunal de Cuentas", en Tribunal de Cuentas, Seminarios, 1984, Madrid, 1985.

Avila Romero, M. y Canales Aliende, J. M.: "Consideraciones en torno al control de la Seguridad Social por el Tribunal de Cuentas", en El control del gasto público, I.E.F., Madrid, 1979, págs. 233 y ss.

Barón CRespo, E.: El control parlamentarios, en "Control del Sector Público", I.E.F., Madrid, 1981.

BAssols COMA, M.: "El principio de buena administración y la función fiscalizadora del Tribunal de Cuentas", en El Tribunal de Cuentas en España, vol. l, I.E.F., Madrid, 1982, págs. 259 y ss.

Bayón Marine, I.: Aprobación y control de los gastos públicos, I.E.F., Madrid, 1972, Cap. VII y VIII.

BENITO ZALDO, R. DE: «Fiscalización específica de la contratación administrativa por el Tribunal de Cuentas", en Tribunal de Cuentas en España, vol. I, I.E.F., Madrid, 1982, págs. 305 y ss. y en Tribunal de Cuentas, Crónica, 1980, Tribunal de Cuentas, Madrid, 1981, págs. 193 y ss.

- "La contratación administrativa y su fiscalización por el Tribunal de Cuentas", en Tribunal de Cuentas, Crónica, 1981, Tribunal de Cuentas, Madrid, 1982, págs. 491 y ss.

Bemejo Vera, J.: "Aspectos jurídicos del procedimiento de actuación del Tribunal de Cuentas", en El Tribunal de Cuentas en España, vol. I, I.E.F., Madrid, 1982, págs. 337 y ss. 
Blanques Avilés, M. J.: "El artículo 41 de la Ley Orgánica del Tribunal de Cuentas", R.E.D.A., no 53, (1987), págs. 55 y ss.

Bohoyos Castañar, F.: "Los ingresos de la Hacienda Pública y la función de control», R.E.D.F., nำ 37 (1983).

Bujidos Garay, P.: "Reflexiones en torno a la función fiscalizadora del Tribunal de Cuentas", en La función de los Tribunales de Cuentas en la sociedad democrática, Tribunal de Cuentas, Madrid, 1985, págs. 73 y ss.

- «En espera de la Ley de Funcionamiento del Tribunal de Cuentas", P.G.P., no 23, (1985).

CACHo Frago, A. del: "Los juicios de cuentas", en Jornadas conmemorativas del décimo aniversario de la aprobación de la Ley Orgánica del Tribunal de Cuentas, de 12 de mayo de 1982, Madrid, 1986

- "Análisis crítico de la Ley de Funcionamiento del Tribunal de Cuentas", en Encuentro sobre aspectos de la coordinación entre el Tribunal de Cuentas y los órganos autonómicos de control externo de las Comunidades Autónomas, Universidad Menéndez Pelayo, Santander, 1993.

Canales Aliende, J. M.: "El Tribunal de Cuentas y la Seguridad Social», en El Tribunal de Cuentas, Crónica, 1980, Tribunal de Cuentas, Madrid, 1981 , págs. 381 y ss.

Canales Aliende, J. M. y Sabate Muro, E.: "Opinión pública, control y participación en la Seguridad Social española», en El control del Sector Público, I.E.F., Madrid, 1981.

Carretero Pérez, A.: «El Tribunal de Cuentas y los aspectos económico, presupuestario y jurídico procedimental del gasto público", en El Tribunal de Cuentas en España, vol. I, I.E.F., Madrid, 1982, págs. 363 y ss.

Cayon Galiardo, A.: "Legalidad y control del gasto público", P.G.P., no 1, (1979).

- «El Tribunal de Cuentas, una perspectiva», P.G.P., no 9, (1981), págs. 47 y ss.

Cazorla Prieto, L. M.: "El control financiero externo y el gasto público en la Constitución", P.G.P., no 2, (1979), págs. 81 y ss.

- «Relaciones del Tribunal de Cuentas en las Cortes Generales», P.G.P., no 12, (1982), págs. 59 y ss.

- "Artículo 31" en Garrido Falla, F. (dir): Comentarios a la Constitución, Madrid, 1985. 
- "Artículo 136", en Garrido Falla, F. (dir): Comentarios a la Constitución, Madrid, 1985.

Corrales Sánchez, E.: "La institución del Tribunal de Cuentas en España y en el extranjero», R.G.L.J., tomo 100, 1902, págs. 225 y ss. y 449 y ss.

Cubillo Rodríguez, C.: "La acción popular", en el orden jurisdiccional contable», en Revista de Derecho Procesal, no 2 (1992).

- "Hacia un proceso único para la jurisdicción del Tribunal de Cuentas", en $A A z$, no 161 (1994).

- "La fase instructora de los procedimientos de reintegro por alcance", en Crónica 1992-1993. Tribunal de Cuentas, Madrid, (1994).

Cuñado Ausin, G.: "El control del crédito oficial", en La función de los Tribunales de Cuentas en la sociedad democrática, Tribunal de Cuentas, Madrid, 1985, págs. 185 y ss.

Domínguez Alonso, M.: "Las relaciones entre las Cortes Generales (Poder Legislativo) y el Tribunal de Cuentas (Organo de control financiero)", en Tribunal de Cuentas, Crónica, 1981. Tribunal de Cuentas, Madrid, 1992, págs. 441 y ss.

- «Responsabilidad de la gestión de fondos y efectos públicos", en Tribunal de Cuentas, Seminarios, 1984". Tribunal de Cuentas, Madrid, 1985, págs. 161 y ss.

Elizalde y Aymerich, P. DE: «La Administración del Estado como parte ante la jurisdicción financiera", en El Tribunal de Cuentas en España, vol. I, Instituto de Estudios Fiscales, Madrid, 1982, págs. 423 y ss.

Entrena Palomero, C. J.: "La función fiscaliziadora del Tribunal de Cuentas sobre los contratos del Estado y organismos autónomos», en El Tribunal de Cuentas en España, vol. I, I.E.F., Madrid, 1982, págs. 465 y ss.

Escribano López, F.: Presupuesto del Estado y Constitución, Madrid, 1981.

EseverRI Martinez, E.: "El control jurídico del gasto público», en El Tribunal de Cuentas en España, vol. I, I.E.F., Madrid, 1982, págs. 477 y ss.

Fanlo Loras, A.: "Relaciones del Tribunal de Cuentas con las Cortes Generales: La Comisión Mixta Congreso-Senado para las relaciones con el Tribunal de Cuentas", R.A.P., no 108 (1985), págs. 329 y ss.

- Relaciones del Tribunal de Cuentas en las Cortes generales, la Comisión Mixta Congreso-Senado para las relaciones con el Tribunal de Cuentas, IEF, Madrid, 1987. 
Fernández-Carnicero González, J. C.: "La Cuenta General del Estado ante el Tribunal de Cuentas y ante el Parlamento", en Funciones Financieras de las Cortes Generales, Congreso de los Diputados, Madrid, 1985, págs. 229 y ss.

- "El artículo 136. El Tribunal de Cuentas", en Comentarios a las Leyes Políticas, Constitución española de 1978, Tomo X, Madrid, 1985.

Fernández Farreres, G.: «El control de las subvenciones a los particulares por el Tribunal de Cuentas", en El Tribunal de Cuentas en España, vol. I, I.E.F., Madrid, 1982, págs. 597 y ss.

- «Problemática del control de las subvenciones por el Tribunal de Cuentas", en Tribunal de Cuentas, Seminarios, 1984, Tribunal de Cuentas, Madrid, 1985, págs. 1 y ss.

- "El control de las subvenciones a los particulares por el Tribunal de Cuentas", en El Tribunal de Cuentas en España, vol. I, I.E.F., Madrid, 1982, págs. 507 y ss.

Fernández Pastrana, J. M.: "Aspectos jurídicos del control financiero de la Seguridad Social", en El control del gasto público, I.E.F., Madrid, 1979, págs. 175 y ss.

Fernández Pirla, J. M.: "El Tribunal de Cuentas en el estado social de Derecho", en La función de los Tribunales de Cuentas en la sociedad democrática, Tribunal de Cuentas, Madrid, 1985, págs. 203 y ss.

- «Expansión funcional y política de los Tribunales de Cuentas: El caso español", en Tribunal de Cuentas de las Comunidades Europeas y los Tribunales de Cuentas de los países miembros: competencias y relaciones. Tribunal de Cuentas, Madrid, 1986, págs. 165 y ss.

- El Tribunal de Cuentas de España, Tribunal de Cuentas, Madrid, 1987.

Fernández Pirla, J. Ma y Sala Sánchez, P.: El Tribunal de Cuentas, ayer y hoy, Tribunal de Cuentas, Madrid, 1987.

Fernández Rodríguez, T. R.: "Perfiles constitucionales del Tribunal de Cuentas", en El Tribunal de Cuentas en España, Vol. I, I.E.F., Madrid, 1982, págs. 15 y ss.

Ferńández-VICTORIO Y CAMPS, S.: El control externo de la actividad financiera de la Administración pública, I.E.F., Madrid, 1977.

- "El Tribunal de Cuentas ante su futura Ley Orgánica", R.A.P., nº 87, (septiembre-diciembre, 1978), págs. 7 y ss. 
- "La jurisdicción del Tribunal de Cuentas», P.G.P., no 10, (1981), págs. 51 y ss.

- «El interés directo, los derechos subjetivos y la acusación particular en el Proyecto de ley sobre el Tribunal de Cuentas", P.G.P., no 11, (1981), págs. 57 y ss.

Fernández-Victorio y de la Fuente, F.: «La fiscalización del Presupuesto de la Administración del Estado y de sus modificaciones", en Tribunal de Cuentas. Seminarios, 1985, Tribunal de Cuentas, Madrid, 1987, págs. 1 y ss.

Ferrín GutiérRez, J. A.: «El control de carácter financiero de los artículos 17 y 18 de la Ley General Presupuestaria», P.G.P., no 12 (1982), págs. 95 y ss.

Ferreiro Lapatza, J. J.: Curso de Derecho Financiero Español, Madrid, 1987.

GARCiA GIL, F.: «Comentarios en torno a la futura Ley Orgánica del Tribunal de Cuentas", P.G.P., no 7, (1980), págs. 75 y ss.

- "La función jurisdiccional del Tribunal de Cuentas", en Tribunal de Cuentas, Crónica, 1980, Tribunal de Cuentas, Madrid, 1981, págs. 163 y ss.

- "La función fiscalizadora del Tribunal de Cuentas", P.G.P., núm. 9, (1981), págs. 105 y ss.

- "Modalidades del control a ejercer por el tribunal de Cuentas en la actuación de su fiscalización sobre las cuentas y gestión económica del Estado y del sector público», en Tribunal de Cuentas, Crónica, 1981, Tribunal de Cuentas, Madrid, 1981, págs. 147 y ss.

- "Los juicios de cuentas: su apertura de oficio", en La función de los Tribunales de Cuentas en la sociedad democrática, Tribunal de Cuentas, Madrid, 1985, págs.

- "Algunas cuestiones relacionadas con la responsabilidad contable", en Tribunal de Cuentas, Seminarios, 1984", Tribunal de Cuentas, Madrid, 1985, págs. 347 y ss.

Garcia Garcia, J. L.: «El control (externo e interno) en la Constitución», en Hacienda y Constitución, I.E.F., Madrid, 1979.

Garcia Gil, F.: "Los juicios de cuentas: su apertura de oficio", en Función de los Tribunales de Cuentas en la Sociedad Democrática. Encuentro Internacional, Santander, 1984, (1995), págs. 445. 
Garcia de LeANIz y de LA ToRRe, P.: «El Tribunal de Cuentas y la contratación administrativa del Estado", en El Tribunal de Cuentas en España, vol. I, I.E.F., Madrid, 1982, págs. 577 y ss.

Garcia Mena, R.: "Novedades de la Ley de Funcionamiento del Tribunal de Cuentas en materia de Fiscalización", en Tribunal de Cuentas, Crónica, 1988-1989, Tribunal de Cuentas, Madrid, 1990, págs. 175 y ss.

Garcia-Trevijano Fos, J. A.: "La nueva Ley Orgánica del Tribunal de Cuentas", R.A.P., no 12, (1953), págs. 239 y ss.

García Vázouez, J.: "La función fiscalizadora del Tribunal de Cuentas y los procedimientos de auditorían, en Tribunal de Cuentas, Seminarios, 1984, Tribunal de Cuentas, Madrid, 1985, págs. 453 y ss.

Gil-Robles y Gil-Delgado, J. M.: Control y Autonomías, Madrid, 1986.

Gisbert IÑESTA, J. L.: «El control de los ingresos públicos por el Tribunal de Cuentas: un análisis de su previsible evolución", en Tribunal de Cuentas, Seminarios, 1985, Tribunal de Cuentas, Madrid, 1987, págs. 253 y ss.

GonzÁlez GaRCía, E.: Introducción al Derecho presupuestario. Concepto, evolución histórica y naturaleza jurídica, Madrid, 1973.

- "Una aproximación al tema de la naturaleza jurídica del Tribunal de Cuentas", en El Tribunal de Cuentas en España, vol. I, I.E.F., Madrid, 1982, págs. 595 y ss.

- "La función fiscalizadora del Tribunal de Cuentas respecto a los ingresos públicos", en Tribunal de Cuentas, Seminarios, 1985, Tribunal de Cuentas, Madrid, 1987, págs. 233 y ss.

González Navarro, F.: «El control de la actuación del Tribunal de Cuentas, R.E.D.A., $\mathrm{n}$ 0 32, (1982), págs. 785 y ss.

GonzÁlez SÁnChez, M.: “El control de los gastos fiscales por el Tribunal de Cuentas», en El Tribunal de Cuentas en España, vol. I, I.E.F., Madrid, 1982, págs. 683 y ss.

González VADillo, I.: "Fiscalización de los ingresos públicos", en La función de los Tribunales de Cuentas en la sociedad democrática, Tribunal de Cuentas, Madrid, 1985, págs. 321 y ss.

González Varas, S.: Financiación de los partidos políticos. Madrid, 1995.

Gutiérrez Robles, A.: "La Cuenta General del Estado", H.P.E., nº 31, (1974), págs. 137 y ss. 
- "Problemática del control de la Empresa pública por el Tribunal de Cuentas», en El Tribunal de Cuentas en España, vol. I, I.E.F., Madrid, 1982, págs. 701 y ss.

- «El control de carácter financiero del sector público estatal», P.G.P., no 15, (1983), págs. y ss.

Herrero Suazo, S.: "Fundamento del control financiero interno y la Constitución", P.G.P., nำ6, (1980).

- "El Tribunal de Cuentas y la Intervención General de la Administración del estado: Concurrencia, competencia e independencia", en El Tribunal de Cuentas en España, vol. I, I.E.F., Madrid, 1982, págs. 741 y ss.

— «Eficacia jurídica de la fiscalización», H.P.E., nº 31 .

Jiménez Hernández, A.: «El expediente administrativo de responsabilidad contable", en Crónica 1990-1991, Tribunal de Cuentas, Madrid, 1992, págs. 71 y ss.

Jiménez Hernández, J. I.: "Aspectos judiciales del Tribunal de Cuentas", en El Tribunal de Cuentas en España, vol. I, I.E.F., Madrid, 1982, págs. 755 y ss.

JUAN ABAD, A. DE: «Los órganos de apoyo en el Tribunal de Cuentas: el Gabinete Técnico", en La función de los Tribunales de Cuentas en la sociedad democrática, Tribunal de Cuentas, Madrid, 1985, págs. 107 y ss.

- "La administración interna del Tribunal de Cuentas", en Tribunal de Cuentas, Seminarios, 1984, Tribunal de Cuentas, Madrid, 1985, págs. 369 y ss.

Langa Mora, E.: «El control de eficiencia y economía por el Tribunal de Cuentas: su relación con el presupuesto por programas", en La función de los Tribunales de Cuentas en la sociedad democrática, Tribunal de Cuentas, Madrid, 1985, págs. 155 y ss.

- "La empresa pública no financiera en España y la problemática de su control», en Tribunal de Cuentas, Seminarios, 1984, Tribunal de Cuentas, Madrid, 1985, págs. 517 y ss.

Linde Paniagua, E.: "El Tribunal de Cuentas y su dependencia directa de las Cortes Generales", en El Tribunal de Cuentas en España, Vol. II, I.E.F., Madrid, 1982, págs. 819 y ss. 
LÓPEZ LÓPEZ, J. C.: «Reflexiones sobre la fiscalización de la contratación administrativa por el Tribunal de Cuentas", en Tribunal de Cuentas, Seminarios, 1985, Tribunal de Cuentas, Madrid, 1987, págs. 91 y ss.

LoRÁn GIMENo, A.: "Acción pública y acción popular», en Tribunal de Cuentas, Seminarios, 1984, Tribunal de Cuentas, Madrid, 1985, págs. 335 y ss.

LOZANO, J.: "Una aproximación al estudio de la naturaleza jurisdiccional del Tribunal de Cuentas", en Boletín de Información del Ministerio de Justicia, $\mathrm{n}^{\mathrm{o}}$ 1667, Madrid, 1993, págs. 84 y ss.

LUCAS Verdú, P.: "Apuntes sobre los aspectos jurídico-políticos del Tribunal de Cuentas", en El Tribunal de Cuentas en España, vol. II, I.E.F., Madrid, 1982, págs. 826 y ss.

LLUCH DE ANDRÉs, J.: "Crisis de las Haciendas Locales y control externo", en Control del sector público, I.E.F., Madrid, 1981, págs. 427 y ss.

Mancebo Coloma, J.: «El control externo sobre la actividad de las Comunidades Autónomas. El control económico y presupuestario", en La función de los Tribunales de Cuentas en la sociedad democrática, Tribunal de Cuentas, Madrid, 1985, págs. 51 y ss.

MAÑEZ VINDEL, J.: "Cuestiones que se plantean en las actuaciones de fiscalización de los Organismos Autónomos Administrativos por el Tribunal de Cuentas", en Tribunal de Cuentas, Seminarios, 1985, Tribunal de Cuentas, Madrid, 1987, págs. 37 y ss.

Marcos Martín, J. L.: «El contenido del control externo de un Estado de estructura compleja: especial referencia al Control de eficacia", en Tribunal de Cuentas, Seminarios, 1985, Tribunal de Cuentas, Madrid, 1987, págs. 281 y ss.

Marcos SANZ, I.: "Modelo constitucional del control del gasto público: pautas para su desarrollo", en Control del Sector Público, I.E.F., Madrid, 1981.

MÁrquez JuRADo, J. M.: "Los manuales de auditoría: una aproximación práctican, en Tribunal de Cuentas, Crónica, 1987, Tribunal de Cuentas, Madrid, 1988, págs. 29 y ss.

- Derechos Fundamentales, Madrid, 1988.

MARTín OAR, L.: «El control de economía, eficiencia y eficacia por el Tribunal de Cuentas: una nota terminológica", en La función de los Tribu- 
nales de Cuentas en la sociedad democrática, Tribunal de Cuentas, Madrid, 1985, págs. 145 y ss.

- "Los objetivos de la Empresa pública y la auditoría de gestión", en Tribunal de Cuentas, Seminarios, 1984, Tribunal de Cuentas, Madrid, 1985, págs. 481 y ss.

Martin Pallín, J. A.: "Infracción y responsabilidad contable», en Tribunal de Cuentas, Seminarios, 1984, Tribunal de Cuentas, Madrid, 1985, págs, 191 y ss.

Martín-Reortillo Baquer, L.: "Las facultades disciplinarias del Tribunal de Cuentas en defensa de sus competencias", en El Tribunal de Cuentas en España, vol. II, l.E.F., Madrid, 1982, págs. 849 y ss.

MaRTínez Gómez, A.: «El análisis económico en las fiscalizaciones del Tribunal de Cuentas", en Tribunal de Cuentas, Crónica, 1981, Tribunal de Cuentas, Madrid, 1982, págs. 731 y ss.

Martinez Gómez, A. y Gisberts Iniesta, J. L.: "El informe anual de los Tribunales de Cuentas. Examen particular del realizado por el Tribunal de Cuentas referido al ejercicio de 1984", en Tribunal de Cuentas de las Comunidades Europeas y los Tribunales de Cuentas de los paises miembros: competencia y relaciones, Tribunal de Cuentas, Madrid, 1986.

Martínez Lafuente, A.: «El Tribunal de Cuentas y el control de los ingresos públicos", R.E.D.F., no 31, (1981), págs. 427 y ss. y en El Tribunal de Cuentas en España, vol. II, I.E.F., Madrid, 1982, págs. 873 y ss.

Martínez López-Muñiz, J. L.: "La Administración Pública para el control parlamentario: El Tribunal de Cuentas», H.P.E., nº 80, (1983), págs. 69 y ss.

Mateu-Ros Cerezo, R.: "El control financiero de los partidos políticos", P.G.P., no 12, (1982), págs. 169 y ss. y en El Tribunal de Cuentas en España, vol. II, I.E.F., Madrid, 1982, págs. 897 y ss.

- "El control financiero de los partidos políticos", P.G.P., no 12, (1982).

Medina Guijarro, J. y Pajares Giménez, J. A.: «La impugnación de los medios de apremio utilizados por el Tribunal de Cuentas en el ejercicio de su función jurisdiccional", en El Tribunal de Cuentas en España, vol. II, Instituto de Estudios Fiscales, Madrid, 1982, págs. 935 y ss.

- "La exigencia de responsabilidades contables en la Ley Orgánica del Tribunal de Cuentas y en la Ley General Presupuestaria", en Función 
de los Tribunales de Cuentas en la sociedad democrática, Santander, 1985, págs. 443 y ss.

- "La jurisdicción contable: contenido y procedimientos", en Revista Española de derecho Financiero, no 74, (1992), págs. 197 y ss.

- "Compatibilidad entre la jurisdicción contable y la jurisdicción penal», en Revista Española de Derecho Financiero, no 81, (1994).

Medina Rubio, R.: «El Tribunal de Cuentas y los principios de la Constitución", en El Tribunal de Cuentas en España, vol. II, I.E.F., Madrid, 1982, págs. 951 y ss.

Mendizabal Allende, R.: "Función y esencia del Tribunal de Cuentas", R.A.P., $\mathrm{n}^{\mathrm{o}} 46,(1965)$, págs. 13 y ss.

- "El Tribunal de Cuentas y su encuadramiento constitucional», en Estudios sobre el proyecto de Constitución, Centro de Estudios Constitucionales, Madrid, 1978, págs. 479 y ss.

- "Tribunal de Cuentas y Tribunal Supremo: un problema de coordinación institucional», en Actualidad Administrativa, no 1 y 2, (1987).

- "El Tribunal de Cuentas y la Constitución", en Control del sector público, IEF, Madrid, 1981, págs. 361 y ss.

- "Organización del Tribunal de Cuentas», en Tribunal de Cuentas, Crónica, 1981, Madrid, 1982.

- "Sector público y Tribunal de Cuentas», P.G.P., no 10, (1981), págs. 77 y ss.

- "La función jurisdiccional del Tribunal de Cuentas", en El Tribunal de Cuentas en España, vol. I, IEF, Madrid, 1982, págs. 63 y ss. y en R.A.P., no 100-102, (1983), vol. II, págs. 1307 y ss.

- «Pasado, presente y futuro de la jurisdicción contencioso-administrativa», en $A A$, no 18 (1994).

Montalvo Correa, J.: "El Tribunal de Cuentas y el control financiero de la Seguridad Social", en Tribunal de Cuentas, Seminarios, 1986, Tribunal de Cuentas, Madrid, 1987, págs. 2 y ss.

Montaño Jiménez, I.: "El control en la Constitución», en Control del Sector Público, I.E.F. 
Moreno Pérez, M.: "Alcance de la función jurisdiccional del Tribunal de Cuentas en la Constitución de 1978: una interpretación histórica y sistemática", en El Tribunal de Cuentas en España, vol. II, I.E.F., Madrid, 1982, págs. 963.

MuÑoz ÁlvAREZ, G.: «El principio de presunción de inocencia en la jurisdicción contable", en Actualidad Jurídica Aranzadi, no 115, (1993).

- «El recurso de apelación en la jurisdicción contable», en Actualidad Jurídica Aranzadi, № 149, (1994).

Muñoz Calvo, J. L.: "Criterios rectores de la fiscalización externa del gasto público. El llamado control de eficacia», en El Tribunal de Cuentas en España, vol. II, I.E.F., Madrid, 1982, págs. 995 y ss.

Murillo Bernáldez, J. F.: "La evolución de las funciones fiscalizadora y jurisdiccional del Tribunal de Cuentas en relación con el art. 12 de la Ley Orgánica de 12 de mayo de 1982", en La función de los Tribunales de Cuentas en la sociedad democrática, Tribunal de Cuentas, Madrid, 1985, págs. 61 y ss.

Nofuentes Garcia-Montoro, M.: "La función jurisdiccional del Tribunal de Cuentas en la Constitución, la doctrina y en la actuación procesal», en El Tribunal de Cuentas en España, vol. II, I.E.F., Madrid, 1982, págs. 1035 y ss.

- "La auditoría gubernamental en el marco de los Tribunales de Cuentas", en La función de los Tribunales de Cuentas en la sociedad democrática, Tribunal de Cuentas, Madrid, 1985, págs. 285 y ss.

- "Control externo de transferencias presupuestarias a partidos políticos, asociaciones profesionales e Iglesia Católica y demás confesiones religiosas", Tribunal de Cuentas, Seminarios, 1984, Tribunal de Cuentas, Madrid, 1985, págs. 23 y ss.

- "Pretensión, alcance y responsabilidades en los procedimientos jurisdiccionales del Tribunal de Cuentas", Tribunal de Cuentas, Seminarios, 1984, Tribunal de Cuentas, Madrid, 1985, págs. 87 y ss.

Núñez-Villaveirán Ovilo, R.: "El sector público, ámbito delimitador de las competencias del Tribunal de Cuentas", en El Tribunal de Cuentas en España, vol. II, I.E.F., Madrid, 1982, págs. 1075 y ss.

Oliva SANTOS, A. DE LA: "Sobre la naturaleza jurisdiccional del Tribunal de Cuentas", R.D.P., no 2, (1985), págs. 339 y ss. y en Tribunal de Cuentas, Seminarios, 1984, Tribunal de Cuentas, Madrid, 1985, págs. 59 y ss. 
Pajares Giménez, J. A.: "La exigencia de responsabilidad contables en la Ley Orgánica del Tribunal de Cuentas y en ella Ley General Presupuestaria", en Tribunal de Cuentas, Seminarios, 1984, Tribunal de Cuentas, Madrid, 1985, págs. 115 y ss.

Pajares Giménez, J. A. y Medina GuiJarro, J.: "Los medios de apremio del Tribunal de Cuentas", en Tribunal de Cuentas, Crónica, 1980, Tribunal de Cuentas, Madrid, 1981, págs. 101 y ss.

- "La exigencia de responsabilidades contables en la Ley Orgánica del Tribunal de Cuentas y en la Ley General Presupuestaria", en La función de los Tribunales de Cuentas en la sociedad democrática, Tribunal de Cuentas, Madrid, 1985, págs. 433 y ss.

- "Documentación comunitaria y legislación estatal y autonómica", en Tribunal de Cuentas, Madrid, 1988.

Palao Taboada, C.: Derecho Financiero y Tributario, Madrid, 1987.

- "El control de la actividad financiera en un Estado democrático" en La función de los Tribunales de Cuentas en la sociedad democrática, Tribunal de Cuentas, Madrid, 1985, págs. 265 y ss.

Pascual García, J.: «Incidencia de la Constitución en el sistema de control financiero", P.G.P., $\mathrm{n}^{\circ}$ 6, (1980).

Pastor Ridruejo, L.: "Problemática del control por el Tribunal de Cuentas de los programas de actividades, financiación e inversiones de las Sociedades estatales", en El Tribunal de Cuentas en España, vol. II, I.E.F., Madrid, 1982, págs. 195 y ss.

Peña Álvarez, F. y Ruiz-Jarabo Colomer, I.: "La fiscalización de las entidades financieras públicas", en La función de los Tribunales de Cuentas en la sociedad democrática, Tribunal de Cuentas, Madrid, 1985, págs. 137 y ss.

Peña Verdaguer, F.: «Impugnación de acuerdos del Tribunal de Cuentas ante la jurisdicción ordinaria", en El Tribunal de Cuentas en España, vol. II, I.E.F., Madrid, 1980, págs. 1113 y ss.

Pérez Royo, F.: "Delimitaciones de funciones del Tribunal de Cuentas", en El Tribunal de Cuentas en España, vol. II. I.E.F., Madrid, 1982, págs. 1131 y ss.

Pérez Royo, J.: «El Tribunal de Cuentas en la Constitución y en el Proyecto de Ley reguladora del mismon, en El Tribunal de Cuentas en España, vol. II, I.E.F., Madrid, 1982, págs. 1141 y ss. 
Pioueras Bautista, J. A.: "Aspectos sustantivos y procesales de la responsabilidad derivada de alcance en la Administración de fondos públicos», en El Tribunal de Cuentas en España, vol. II, I.E.F., Madrid, 1982, págs. 1155 y ss.

Pradel Alfaro, A. y Fernández-Victorio, F.: «El control de la Seguridad social por el Tribunal de Cuentas"), en Tribunal de Cuentas, Crónica, 1981, Madrid, 1982, págs. 27 y ss.

Pujalte Clariana, E.: "Teleología de la acción pública contable», Seminario 1984, Tribunal de Cuentas, Madrid, 1985.

QUeRol BelLido, V.: «Independencia y organización del control financiero en España», P.G.P., nº 16, (1983), págs. 125 y ss.

Quintana López, T.: «El Tribunal de Cuentas y la teoría estatutaria del Derecho Administrativo", R.A.P., (1988).

Ranz Periáñez, E.: "Breve aproximación a la fiscalización de las prestaciones sociales de contenido económico, en La función de los Tribunales de Cuentas en la sociedad democrática, Tribunal de Cuentas, 1985, págs. 375 y ss.

Raquejo Alonso, A.: "Las Cortes como instrumento de control de la Administración Económica del Estado", R.D.F., no 72, (1967), págs. 1099 y ss.

Redondo de LA VEGA, J.: "Análisis de los principios de economía, eficiencia y eficacia aplicados a la auditoría de optimización de recursos", en Tribunal de Cuentas, Crónica, 1988-1989, Tribunal de Cuentas, Madrid, 1990 , págs. 277 y ss.

Reus García-Bedoya, J. M.: "El control del Tribunal de Cuentas en la contratación de material militar en el extranjero", en Tribunal de Cuentas, Seminarios, 1985, Tribunal de Cuentas, Madrid, 1987, págs. 55 y ss.

Reyes Monterreal, J. M.: "Aspecto jurisdiccional del Tribunal de Cuentas", en El Tribunal de Cuentas en España, vol. II, I.E.F., Madrid, 1982, págs. 1239 y ss.

Rodrigo Sanz, A. M. y Fuenmayor Fuenmayor, C.: "El informe de auditoríai, en La función de los Tribunales de Cuentas en la sociedad democrática, Tribunal de Cuentas, Madrid, 1985, págs. 177 y ss.

Rodriguez Ferrer, M. E.: "El control de las subvenciones por el Tribunal de Cuentas. Su problemática», en Tribunal de Cuentas, Seminarios, 1984, Tribunal de Cuentas, Madrid, 1985, págs. 37 y ss. 
Rodríguez Alique, M. A.: «Examen del artículo 82 de la Ley de Funcionamiento del Tribunal de Cuentas, de 7 de abril de 1988", en Justicia 92, (1992), págs. 621 y ss.

Rodríguez Oliver, J. M.: "Tribunal de Cuentas, Tribunal Supremo y Tribunal Constitucional", en El Tribunal de Cuentas en España, vol. II, I.E.F., Madrid, 1982, págs. 1251 y ss.

Rosiñol VIDAL, C.: La responsabilidad contable y la gestión de los recursos públicos, Escola D'Administració Pública de Catalunya y Sindicatura de Comptes de Catalunya, Barcelona, 1994.

- "Aproximación a las actuines previas a la exigencia de responsabilidades contables", en Crónica 1992-1993. Tribunal de Cuentas, Madrid, (1994), págs. 427 y ss.

Rubio Moradillo, J. M.: "Hacia un concepto de alcance", en Tribunal de Cuentas, Madrid, 1985, págs. 171 y ss.

Rubio Moradillo, J. M. y Sáinz de Baranda y González Arnao , J. M.: «El objeto de la responsabilidad contable", en La función de los Tribunales de Cuentas en la sociedad democrática, Tribunal de Cuentas, Madrid, 1985 , págs. 423 y ss.

Ruiz-Ayucar, J. y Antonaya Suja, A. L.: "El control parlamentario de la eficacia del gasto público, en Análisis de la Ley General Presupuestaria, I.E.F., Madrid, 1977, págs. 247 y ss.

Ruiz-Jarabo Colomes, l.: "Relación entre los controles de legalidad y de eficiencia y economía en la fiscalización del Tribunal de Cuentas", en Tribunal de Cuentas, Seminarios, 1984, Tribunal de Cuentas, Madrid, 1985 , págs. 493 y ss.

SaIG Grau, J. A.: "La informática en el control externo del sector público y sus relaciones con el control interno", en Función de los Tribunales de Cuentas en la Sociedad democrática, Tribunal de Cuentas, Madrid, 1985.

Sáinz de Baranda y González Arnau, J. M.: "Análisis de las responsabilidades contables", en Tribunal de Cuentas, Seminarios, 1984, Tribunal de Cuentas, Madrid, 1985, págs. 131 y ss.

Sáinz de Bujanda, F.: Lecciones de Derecho Financiero, Madrid, 1979.

SÁINZ de Robles, F. C.: «Relaciones entre la jurisdicción ordinaria y la jurisdicción contable", en La función de los Tribunales de Cuentas en la sociedad democrática, Tribunal de Cuentas, Madrid, 1985, págs. 457 y ss. 
SALA SÁnCHEZ, P.: La jurisdicción contable. Las responsabilidades contables y su enjuiciamiento en la nueva Ley Orgánica del Tribunal de Cuentas en España, Tribunal de Cuentas, Madrid, 1984.

- «El enjuiciamiento contable en el nuevo Tribunal de Cuentas de España", en La función de los Tribunales de Cuentas en la sociedad democrática, Tribunal de Cuentas, Madrid, 1985, págs. 399 y ss.

- «Nuevos aspectos de la jurisdicción contable en el Tribunal de Cuentas de España», Tribunal de Cuentas, Madrid, 1987.

- "La Constitución, la Ley Orgánica del Tribunal de Cuentas y su Ley de funcionamiento", Revista de Administración Pública, no 122, (1990), págs. 131 y ss.

Sales Cargallo, F.: "Reflexiones sobre el control de legalidad», P.G.P., no 10, (1981), págs. 109 y ss.

San Segundo Arribas, M.: "Jurisdicción y acción popular", en tribunal de Cuentas, Seminarios, 1984, Tribunal de Cuentas, Madrid, 1985, págs. 241 y ss.

- "El control a través del Tribunal de Cuentas", en Tribunal de Cuentas, Crónica, 1987, Tribunal de Cuentas, Madrid, 1988, págs. 101 y ss.

SÁnCHEZ Motos, E.: "Sugerencias para mejorar el control de eficacia del gasto públicon, P.G.P., núm. 20, (1984), págs. 69 y ss.

Santamaría Pastor, J. A.: "Ante la reforma de las funciones del Tribunal de Cuentas", R.E.D.A., no 31, (1981), págs. 631 y ss.

- "El control a través del Tribunal de Cuentas, en Crónica 1987. Tribunal de Cuentas, Madrid, 1988, págs. 101 y ss.

SANTAOLAlla López, F.: Las funciones parlamentarias en relación con los órganos auxiliares del Parlamento, Madrid, 1990.

Sanz Mulas, A. y Martinez Gómez, A.: "Hacia una nueva concepción del control externo de la actividad financieran, en Control del Sector Público, I.E.F., Madrid, 1981, págs. 401 y ss.

Sanz Ramírez, A.; Sanz Mulas, A. y Martínez Gómez, A.: "Las nuevas técnicas presupuestarias y el control del Tribunal de Cuentas", en Tribunal de Cuentas, Crónica, 1981, Tribunal de Cuentas, Madrid, 1982, págs. 247 y ss.

Serra Rexach, E.: "El Tribunal de Cuentas y la Empresa Pública», en El Tribunal de Cuentas en España, vol. I, I.E.F., Madrid, 1982, págs. 113 y ss. 
Serrano Triana, A.: "El Tribunal de Cuentas y la Seguridad Social, en El Tribunal de Cuentas en España, vol. II, I.E.F., Madrid, 1980, págs. 1329 y ss.

Simón Diaz, L.: "Del enjuiciamiento por la jurisdicción contable de los activos administrativos de carácter discrecional", en La función de los Tribunales de Cuentas en la sociedad democrática, Tribunal de Cuentas, Madrid, 1985, págs. 419 y ss.

- "De las responsabilidades contables», en Tribunal de Cuentas, Seminarios, 1984, Tribunal de Cuentas, Madrid, 1985, págs. 105 y ss.

SOLA FERNÁNDEZ, M. F.: "Aproximación al estudio de la compatibilidad entre la jurisdicción contable y la jurisdicción penal", en Tribunal de Cuentas, Crónica, 1987, Tribunal de Cuentas, Madrid, 1988, págs. 141 y ss.

- "La acción pública en la Ley de Funcionamiento del Tribunal de Cuentas", en Crónica 1990-1991. Tribunal de Cuentas, Madrid, 1992, págs. 91 y ss.

SuÁrez SuÁrez, A. S.: "El control de economía, eficiencia y eficacia en la Constitución y en la Ley Orgánica del Tribunal de Cuentas", H.P.E., $\mathrm{n}^{\circ}$ 80, (1983).

- La empresa pública y su control, Tribunal de Cuentas, Madrid, 1984.

- El control o fiscalización del sector público. Auditorías de eficiencia, Tribunal de Cuentas, Madrid, 1986.

Subirats Piñana, J.: "La función fiscalizadora en el nuevo Tribunal de Cuentas de España", en La función de los Tribunales de Cuentas en la sociedad democrática, Tribunal de Cuentas, Madrid, 1985, págs. 31 y ss.

TEnorio MACIAS, P.: "El control parlamentario de la Seguridad Social", en El control del gasto público, I.E.F., Madrid, 1981, págs. 113 y ss.

Tenorio SánChez, P. J.: "Las garantías de la función de control", R.D.P., no 30, (1989).

Toledo Jaudenes, J.: «El principio de oficialidad y el procedimiento de la jurisdicción contable», R.E.D.A., no 43, (1984), págs. 593 y ss.

Tome Robla, B.: "Relaciones entre el Tribunal de Cuentas y las Cortes Generales", en La función de los Tribunales de Cuentas en la sociedad democrática, Tribunal de Cuentas, Madrid, 1985, págs. 311 y ss.

TORREs BouRSAULT, L.: "Democracia y control financiero", en Función de los Tribunales de Cuentas en la sociedad democrática, Tribunal de Cuentas, Madrid, 1985. 
Triana Reyes, B. y Torres Fernández, J. J.: "Las relaciones entre las jurisdicciones contable y penal", en $A A, n^{\circ} 48$, (1992), págs. 571 y ss.

Tribunal de Cuentas: Declaración definitiva de la Cuenta General del Estado de 1988, Madrid, 1989.

Tribunal de Cuentas: Declaración definitiva de la Cuenta General del Estado de 1989, Madrid, 1990.

Tribunal de Cuentas: Declaración definitiva de la Cuenta General del Estado de 1990, Madrid, 1991.

Tribunal de Cuentas: Declaración definitiva de la Cuenta General del Estado de 1991, Madrid, 1992.

Tribunal de Cuentas: Declaración definitiva de la Cuenta General del Estado de 1992, Madrid, 1993.

Tribunal de Cuentas: Declaración definitiva de la Cuenta General del Estado de 1992, Madrid, 1994.

Tribunal de Cuentas: Declaración definitiva de la Cuenta General del Estado de 1993, Madrid, 1995.

Tribunal de Cuentas: Informe anual del ejercicio 1984, Madrid, 1985.

TRIBUNAL DE CUENTAS: Informe anual sobre la gestión del sector público 1987, Madrid, 1988.

TriBUnAL dE CUENTAS: Informe anual sobre la gestión del sector público 1988, Madrid, 1989.

TriBUnAL de Cuentas: Informe anual sobre la gestión del sector público 1989, Madrid, 1990.

TriBUnAL dE CUENTAS: Informe anual sobre la gestión del sector público 1990, Madrid, 1991.

TriBUnAL de CUENTAS: Informe anual sobre la gestión del sector público 1991, Madrid, 1992.

Tribunal de Cuentas: Documentación Comunitaria y Legislación Estatal y Autonómica. Madrid, 1988.

TRIBUNAL DE CUENTAS: Informe anual sobre la gestión del sector público 1992, Madrid, 1993. 
TribunAL DE CUenTAS: Informe anual sobre la gestión del sector público 1993, Madrid, 1994.

TRIBUnAL dE CuENTAS: Informe anual sobre la gestión del sector público 1994, Madrid, 1995.

Trillo-Figueroa M. Conde, F.: "La función consultiva del Tribunal de Cuentas ante la crisis de la institución parlamentaria», en El Tribunal de Cuentas en España, vol. II, I.E.F., Madrid, 1982, págs. 1387 y ss.

Turiel Sandin, F.: "El control de las Delegaciones de Hacienda por el Tribunal de Cuentas", en Tribunal de Cuentas, Seminarios, 1985, Tribunal de Cuentas, Madrid, 1987, págs. 269 y ss.

URIAS VAliente, J.: "Auditoría y fiscalización en el Tribunal de Cuentas. Especial referencia a las sociedades estatales", en Tribunal de Cuentas, Seminarios, 1984, Tribunal de Cuentas, Madrid, 1985, págs. 435 y ss.

VACAS Garcia-Alos, L.: "La casación en lo contencioso-administrativo y su atingencia con la jurisdicción contablen, en B/CAM, $n^{\circ} 4$ (1990), págs. 31 y ss.

- "Prioridad de la jurisdicción contable sobre la penal en la determinación de la responsabilidad civil nacida de los delitos", en BIMJ, no 1622 y 1623, (1992), págs. 270 y ss.

Vacas Garcia-Alos, L. y Monzó Torres, J. L.: "Consideraciones sobre la naturaleza jurídica de las actuaciones instructoras en el procedimiento de reintegro por alcance», en $A A$, no 24 y 25, (1990), págs. 263 y ss.

Vallverdu Calafell, J.: "Las finanzas públicas y su control. El Tribunal de cuentas y la auditoría contable», R.E.F.C., no 44, (1984).

VICARIO, C.: "Reflexiones en torno al Fondo de Compensación Interterritorial» (F.C.I.), en Tribunal de Cuentas, Crónica, 1988-1989, Tribunal de Cuentas, Madrid, 1990, págs. 257 y ss.

VV.AA.: Memorias del Tribunal de Cuentas del Reino: presentadas y reproducidas en la Legislatura de 1877, España, Tribunal de Cuentas, Imp. Madrid, 1877.

VV.AA.: Manual para uso de los señores senadores, Madrid, 1910.

VV.AA.: El control del gasto público, III Jornadas sobre control de la actividad financiera de la Administración Pública. Cuerpo de Intervención y Contabilidad de la Administración Civil del Estado, Madrid, 1979. 
VV.AA.: Control del sector público, IV Jornadas sobre control de la actividad financiera de la Administración Pública, Cuerpo de Intervención y Contabilidad de la Administración Civil del Estado. Madrid, 1982.

VV.AA.: El control económico-financiero de los fondos públicos en una sociedad democrática, I Jornadas de la Cámara de Comptos de Navarra, Pamplona, 1983.

VV.AA.: Tribunal de Cuentas: Trabajos parlamentarios, España, Cortes Generales, Madrid, 1984.

VV.AA:: La función de los Tribunales de Cuentas en la sociedad democrática, Encuentro Internacional, Santander, 1984, Tribunal de Cuentas, Madrid, 1985.

VV.AA.: Tribunal de Cuentas del Reino, Seminarios, 1984, Tribunal de Cuentas, Madrid, 1984.

VV.AA.: Tribunal de Cuentas Seminarios, 1985, Tribunal de Cuentas, Madrid, 1987.

VV.AA.: Tribunal de Cuentas Seminarios, 1986, Tribunal de Cuentas, Madrid, 1987.

VV.AA.: Encuentro entre los Presidentes de los Tribunales de Cuentas de las Comunidades Europeas, Tribunal de Cuentas, $2^{\mathrm{a}}$ ed., Madrid, 1986.

Zambrano Chico, F.: «El control económico-financiero de la Seguridad Social en Españan, P.G.P., no 15, (1983), págs. 123 y ss.

\section{EL CONTROL ECONÓMICO-FINANCIERO EN LAS COMUNIDADES AUTONOMAS Y EN EL ÁMBITO MUNICIPAL}

Albiñana Garcia-Quintana, C.: "El control externo de las actividades económicas y financieras de las Comunidades Autónomas", P.G.P., $\mathrm{n}^{\circ}{ }^{\mathbf{5}}$, (1980), págs. 53 y ss.

ARAGón SÁNCHEz, C.: "El control económico financiero de las Corporaciones Locales. Situación actual", en I/ Encuentros del Tribunal de Cuentas, Crónica, 1981, vol. I, Madrid, 1982, págs. 155 y ss.

- «El control de la actividad económico-financiera de las Corporaciones locales", en El Tribunal de Cuentas en España, vol. I, I.E.F., Madrid, 1982 , págs. 235 y ss. 
- "La contabilidad de las Corporaciones Locales y la función asesora del Tribunal de Cuentas en Españan, en La función de los Tribunales de Cuentas en la sociedad democrática, Tribunal de Cuentas, Madrid, 1985, págs. 85 y ss.

- "Controles externos de la actividad económica-financiera del sector público (especiales referencias a las Corporaciones Locales)", en tribunal de Cuentas, Seminarios, 1985, Tribunal de Cuentas, Madrid, 1987, págs. 163 y ss.

- El Tribunal de Cuentas y los controles financieros externos de la Administración del Estado y de las Comunidades Autónomas en las Corporaciones Locales, IEF, Madrid, 1988.

- "Control financiero, fiscalización, función interventora y auditoría (especial referencia a las Corporaciones Locales)", en Tribunal de Cuentas, Crónica, 1988-1989, Tribunal de Cuentas, Madrid, 1990, págs. 301 y ss.

Bautista Pérez, F.: "Criterios de competencias del Tribunal de Cuentas y las Comunidades Autónomas", P.G.P., no 9 (1981), págs. 9 y ss. y en EI Tribunal de Cuentas en España, vol. I, I.E.F., Madrid, 1982, págs. 287 y ss.

Bermejo Garde: Notas sobre los órganos de control esterno de las Comunidades históricas, IEF, Madrid, 1987.

Blanco Herranz, F. J.: Los Órganos dependientes del Parlamento Vasco, Parlamento Vasco, Vitoria, 1991.

Capdevila Salva, J.: "El ámbito del sector público en la autonomía. La fiscalización externa y la Sindicatura de Comptes de Catalunya", P.G.P., no 19, (1984), págs. 45 y ss.

Cazorla Prieto, L. M.: «El control de las Corporaciones locales por el Tribunal de Cuentas", en El Tribunal de Cuentas en España, vol. I, I.E.F., Madrid, 1982, págs. 147 y ss. y también en IEAL, 1982. Colección "Estudios".

CheCA González, C.: Justicia contable y Comunidades Autónomas en España, Padova, 1990.

Díaz Contreras, L.: "Consideraciones sobre la financiación básica de las Comunidades Autónomas y su control por el Tribunal de Cuentas", en Tribunal de Cuentas, Seminarios, 1985, Tribunal de Cuentas, Madrid, 1987, págs. 309 y ss. 
Diez Moreno, F.: "Las especialidades catalana y gallega en materia de fiscalización de las cuestas de la gestión económican, en El Tribunal de Cuentas de España, vol. I, I.E.F., Madrid, 1982, págs. 405 y ss.

Fanlo LoRAs, A.: El Tribunal de Cuentas y las Corporaciones Locales, I.E.A.L., Madrid, 1986.

Fernández-Carnicero González, C. J.: «El control de la actividad económica de las Comunidades Autónomas por el Tribunal de Cuentas", en El Tribunal de Cuentas de España, vol. I, I.E.F., Madrid, 1982, págs. 495 y ss.

Fernández Cuevas, A.: "Las funciones financieras de las Cortes Generales en relación con las Comunidades Autónomas", en Funciones financieras de las Cortes generales, Congreso de los Diputados, Madrid, 1985, págs. 265 y ss.

Fernández Junquera, M.: "Notas sobre el Tribunal de Cuentas y las Comunidades Autónomas", P.G.P., no 19, (1984), págs. 77 y ss.

Fernández-Victorio Y dE LA Fuente, F.: "La superación del término "cuentadante" en el control de la Hacienda autonómica", en El Tribunal de Cuentas de España, vol. I, I.E.F., Madrid, 1982, págs. 535 y ss.

- "El Tribunal de Cuentas y las Comunidades Autónomas", en Tribunal de Cuentas, Crónica, 1980, Tribunal de Cuentas, Madrid, 1981, págs. 117 y ss.

Garcia García, J. L.: "La institución estatutaria de Tribunales de Cuentas en las Comunidades Autónomas", en el Tribunal de Cuentas en España, vol. I, I.E.F., Madrid, 1982, págs. 561 y ss.

González García, E.; González Sánchez, M. y Vega Herrero, M.: “El control de los gastos público de las Corporaciones Locales por el Tribunal de Cuentas", R.H.A.L., no 41, (1984), págs. 237 y ss.

Hervas Cuartero, E.: Ley Orgánica del Tribunal de Cuentas, Instituto Nacional de Prospectiva, Madrid, 1980.

Herrero Suazo, S.: "El control de las Autonomías", en El control del sector publico, I.E.F., Madrid, 1981, págs. 463 y ss.

- «El control por las Cortes Generales de la actividad financiera de las Comunidades Autónomas", en Funciones Financieras de las Cortes Generales, Congreso de los Diputados, Madrid, 1985, págs. 381 y ss. 
Jiménez LUNA, P. A.: «El Tribunal de Cuentas y la descentralización de las técnicas de fiscalización sobre las Corporaciones Locales", en El Tribunal de Cuentas en España, vol. II, I.E.F., Madrid, 1982, págs. 805 y ss.

Ley Orgánica del Tribunal de Cuentas: Trabajos parlamentarios, Congreso de los Diputados, Secretaría General, Madrid, 1984.

Mateu-Ros Cerezo, R.: "El control de la legalidad de la actividad económico-financiera de las Comunidades Autónomas y Corporaciones Locales", en Organización territorial del Estado, vol. III, I.E.F., Madrid, 1984, págs. 1989 y ss.

MendizÁbal Allende, R.: "La fiscalización financiera de las Comunidades Autónomas", en Organización territorial del Estado (Comunidades Autónomas), vol. IV, I.E.F., Madrid, 1984, págs. 2169 y ss.

Muı́ı GoÑı, Mạ P.: La Cámara de Comptos de Navarra entre 1328-1512, con precedentes desde 1258, Gobierno de Navarra, Pamplona, 1988.

MURUZÁBAL LeRGA, J. S.: "Una aproximación a los Tribunales de cuentas no estatales: la Cámara de Comptos de Navarra", en La función de los Tribunales de Cuentas en la sociedad democrática, Tribunal de Cuentas, Madrid, 1985, págs. 305 y ss.

Navarro Palacios, M.: "La empresa mixta local y el Tribunal de Cuentas", en El Tribunal de Cuentas en España, vol. II, I.E.F., Madrid, 1982, págs. 1017 y ss.

ORDOQUI URDACI, L.: "El control regional de la actividad financiera en la España autonómica», en La función de los Tribunales de Cuentas en la sociedad democrática, Tribunal de Cuentas, Madrid, 1985, págs. 295 y ss.

Orón Moratal, G.: "El control externo de la actividad económica de las Comunidades Autónomas: la Sindicatura de Cuentas", P.G.P., no 20, (1984), págs, 55 y ss.

Pajares Giménez, J. A.: "La exigencia de responsabilidad contables en la Ley Orgánica del Tribunal de Cuentas y en la Ley General Presupuestaria", en Tribunal de Cuentas, Seminarios, 1984, Tribunal de Cuentas, Madrid, 1985, págs. 115 y ss.

Pajares Giménez, J. A. y Medina Guijarro, J.: Tribunal de Cuentas, documentación comunitaria y legislación estatal autonómica, Madrid, 1987.

Pizarro Moreno, M.: La fiscalización de la actividad financiera de los entes preautonómicos, en "El Tribunal de Cuentas en España», vol. II, I.E.F., Madrid, 1982, págs. 1185 y ss. 
Ramallo Massanet, J.: «El control de la Hacienda no estatal por el Tribunal de Cuentas", en El Tribunal de Cuentas de España, vol. II, I.E.F., Madrid, 1982, págs. 1215 y ss.

Rosa Alemany, A. DE LA: "Las subvenciones del Estado a los municipios", en Tribunal de Cuentas, Seminarios, 1985, Tribunal de Cuentas, Madrid, 1985, págs. 47 y ss.

Ruiz-Beato Bravo, J.: "Fiscalización de la actividad económica de las Corporaciones Locales por el Tribunal de Cuentas", en El Tribunal de Cuentas en España, vol. II, I.E.F., Madrid, 1982, págs. 1267 y ss.

Sánchez Agesta, L.: "El Tribunal de Cuentas y las Autonomías", en Tribunal de Cuentas, Crónica, 1980, Tribunal de Cuentas, Madrid, 1981, págs. 217 y ss.

- El Tribunal de Cuentas y las Comunidades Autónomas, en "El Tribunal de Cuentas en Españan, vol. II, I.E.F., Madrid, 1982, págs. 1283 y ss.

Sánchez Serrano, L.: «El control económico y presupuestario de las Comunidades Autónomas por el Tribunal de Cuentas, en El Tribunal de Cuentas en España, vol. II, I.E.F., Madrid, 1982, págs. 1303 y ss.

Santamaria Pastor, J. A.: "Las Comunidades Autónomas y el control económico-financiero", P.G.P., no 13, (1982), págs. 121 y ss.

SOSA WAGNER, F.: "El control contable y presupuestario de las Corporaciones Locales", P.G.P., no 13, (1982), págs. 131 y ss.

- "Tribunal de Cuentas y autonomías territoriales", en El Tribunal de Cuentas en España, vol. II, I.E.F., Madrid, 1982, págs. 1367 y ss.

Sosa Wagner, F. y Bocanegra Sierra, R.: "El control contable del Estado y las Corporaciones Locales y el cambio constitucional", H.P.E., $n^{0} 59$, (1979), págs. 169 y ss.

Ureta Domingo, J. C.: «El poder de gasto de las Comunidades Autónomas: elementos que lo componen y modalidades de control en el Estado de Autonomías", en El Tribunal de Cuentas en España, vol. II, I.E.F., Madrid, 1982, págs. 1421 y ss.

Vicente-ArChe Domingo, F.: "El Tribunal de Cuentas y las Comunidades Autónomas", R.E.D.F., no 32, (1981), págs. 597 y ss. y en El Tribunal de Cuentas en España, vol. I, I.E.F., Madrid, 1982, págs. 183 y ss.

VV.AA.: Tribunal Vasco de Cuentas Públicas, Tribunal Vasco de Cuentas, Vitoria, 1993. 
VV.AA.: Lei do Consello de Contas de Galicia, Galicia, 1988.

VV.AA.: Ley y Reglamento de la Cámara de Cuentas de Andalucía, Cámara de Cuentas de Andalucía, 1991.

\section{EL CONTROL ECONÓMICO-FINANCIERO EN LAS COMUNIDADES EUROPEAS Y EN EL DERECHO EXTRANJERO}

Alabau I Oliver, Ma . M.: El control externo por los Tribunales de Cuentas de la Europa Comunitaria, I.E.F., Madrid, 1990.

- La Unión Europea ante el reto de controlar sus recursos: el Tribunal de Cuentas Europeo, garante de la aplicación de los recursos de los ciudadanos de la Unión Europea, IEF, Madrid, 1995.

Aragón Sánchez, C.: "El nuevo Tribunal de Cuentas de España y las Corporaciones Localesn, en Tribunal de Cuentas de las Comunidades Europeas y los Tribunales de Cuentas de los países miembros: competencias y relaciones. Tribunal de Cuentas, Madrid, 1986, págs. 185 y ss.

BAYOD, M.: "Control externo de las sociedades estatales en Francia», en Tribunal de Cuentas, Crónica, 1981, Tribunal de Cuentas, Madrid, 1982, págs. 319 y ss.

Bautista Pérez, F.: «Algunas notas sobre el Tribunal de Cuentas en las Comunidades Europeas", P.G.P., no 6, Madrid, 1980, págs. 69 y ss.

BroesigKe, T.: «El Tribunal de Cuentas en Austria», en La función de los Tribunales de Cuentas en la sociedad democrática, Tribunal de Cuentas, Madrid, 1985, págs. 253 y ss.

- "Cooperación entre las entidades Fiscalizadoras Superiores", en Tribunal de Cuentas de las Comunidades Europeas y los Tribunales de Cuentas de los paises miembros: competencias y relaciones, Tribunal de Cuentas, Madrid, 1986, págs. 33 y ss.

Calaniello, V. y otros: Scritti in memoria di Antonio de Stefano, Milano, 1990.

CAPIELlo, R.: «El Tribunal de Cuentas de Italia», en Tribunal de Cuentas, Crónica, 1981, Madrid, 1982. 
Clemente, G.: "La Cour des Comptes italienne: Les competences actuelle et les perspectives futures. Les rapports avec la Cour des Comptes Européenne", en Tribunal de Cuentas de las Comunidades Europeas y los Tribunales de Cuentas de los países miembros: competencias y relaciones, Tribunal de Cuentas, Madrid, 1986, págs. 135 y ss.

Corrales Sanchez, E.: "La Institución del Tribunal de Cuentas en España y en el extranjero», R.G.L.J., tomo 100, 1902, págs. 225 y ss. y 449 y ss.

Chandernagor, A.: "El Tribunal de Cuentas en Francia», en La función de los Tribunales de Cuentas en la sociedad democrática, Tribunal de Cuentas, Madrid, 1985, págs. 221 y ss.

- "La Cour des Comptes des Communautés Européennes et les institutions de contrôle des pays membres; competence et relations", en Tribunal de Cuentas de las Comunidades Europeas y los Tribunales de Cuentas de los paises miembros: competencias y relaciones, Tribunal de Cuentas, Madrid, 1986, págs. 79 y ss.

Defor, A.: «Coordination et coopération des Cours des Comptes Nationales et plus specialement de celle de la Belgique avec la Cour des Comptes Européenne", en Tribunal de Cuentas de las Comunidades Europeas y Tribunales de Cuentas de los países miembros: Competencias y relaciones, Tribunal de Cuentas, Madrid, 1986, págs. 51 y ss.

Descheemaeker, C.: "La Cour des Comptes", en Notes et Etudes Documentaires, nº 4957, (1992), págs. 173-191.

DOWNEY, G.: "The role of the United Kingdom National Audit Office", en Tribunal de Cuentas de las Comunidades Europeas y los Tribunales de Cuentas de los países miembros: competencias y relaciones, Tribunal de Cuentas, Madrid, 1986, págs. 93 y ss.

Escobedo MANSILLA, R.: Control fiscal en el virreinato peruano: El Tribunal de Cuentas, Madrid, 1986.

Esperón LÁzARo, J. A.: «El Tribunal de cuentas de la Comunidad Económica Europea ante los dos modelos tipos de control externo: Francia y Gran Bretañan, en Tribunal de Cuentas de las comunidades Europeas y los Tribunales de Cuentas de los países miembros: competencias y relaciones, Tribunal de Cuentas, Madrid, 1986, págs. 209 y ss.

Espinosa Fernández, A.: «El control externo de los ingresos y los gastos comunitarios: El Tribunal de Cuentas de las Comunidades Europeas", en Tribunal de Cuentas de las Comunidades Europeas y los Tribunales de Cuentas de los paises miembros: competencias y relaciones, Tribunal de Cuentas, Madrid, 1986, págs. 217 y ss. 
Fernández, M. F.: «El Tribunal de Cuentas de las Comunidades Europeas: Estructura, organización y competencias", en Tribunales de Cuentas de las Comunidades Europeas y los Tribunales de Cuentas de los países miembros: competencia y relaciones, Tribunal de Cuentas, Madrid, 1986, págs. 237 y ss.

Fernández Farreres, G.: «El control por la Comunidad Económica Europea de las subvenciones y ayudas financieras", P.G.P., no 12, (1982), págs. 75 y ss.

Fernández Segura, L. y Garcia Vázouez, J.: «El control de la gestión financiera de los fondos comunitarios. Las posibles relaciones del Tribunal de Cuentas Comunitario y del Tribunal de Cuentas español para facilitar este control», en Tribnal de Cuentas de las Comunidades Europeas y los Tribunales de Cuentas de los países miembros: competencias y relaciones, Tribunal de Cuentas, Madrid, 1986, págs. 223 y ss.

GALÁN GIL, F.: «El control externo en Gran Bretaña», P.G.P., no 5, (1980), págs. 237 y ss.

García García, M.: "Una tipología básica de los Tribunales de Cuentas: su aplicación al análisis del Tribunal de Cuentas Federal de la República Alemana y a una propuesta de organización para el Tribunal de Cuentas del Reino", en Tribunal de Cuentas, Crónica, 1981, Madrid, 1982.

Garcia Garcia, M.; Galán Gil, C.; Cruz Jiménez, A. y Lucini Gaudi, P.: "La Cour des Comptes des Communautés Européennes», en Tribunal de Cuentas de las Comunidades Europeas y los Tribunales de Cuentas de los países miembros: competencias y relaciones, Tribunal de Cuentas, $\mathrm{Ma}$ drid, 1986, págs. 23 y ss.

IANNOTtA, R.: /l problema del controllo preventivo di legittimità delle fonti primarie governative, Milano, 1972.

Jover Moreno, M.; Medina Guijarro, J.; Pajares Giménez, J. A. y Sola Kordes, F. G.: "The Court of Audit in the Netherlands: a changing approach", en Tribunal de Cuentas de las Comunidades Europeas y los Tribunales de Cuentas de los países miembros, Tribunal de Cuentas, Madrid, 1986, págs. 111 y ss.

LELONG, P.: «El Tribunal de Cuentas de las Comunidades Europeas: composición y funcionamiento", P.G.P., nº 20, (1984), págs. 181 y ss.

- "El Tribunal de Cuentas en la Comunidad Económica Europea", en La función de los Tribunales de Cuentas en la sociedad democrática, Tribunal de Cuentas, Madrid, 1985, págs. 207 y ss. 
Mancebo Coloma, J.; Rodríguez Fernández, M. C.; Cabello Pérez, M. T. y Rodriguez Martínez, I.: "Control externo de la Seguridad Social en el Reino Unido", en Tribunal de Cuentas, Crónica, 1981, Tribunal de Cuentas, Madrid, 1982, págs. 395 y ss.

Márouez Gutiérrez, J. M.: «El Tribunal de Cuentas en el marco de las Comunidades Europeas", en Tribunal de Cuentas de las Comunidades Europeas y los Tribunales de Cuentas en los paises miembros: competencias y relaciones, Tribunal de Cuentas, Madrid, 1986, págs. 249 y ss.

McDonnel, P.: "The Office of the Comptroller and Auditor General", en Tribunal de Cuentas de las Comunidades Europeas y los Tribunales de Cuentas de los países miembros, Tribunal de Cuentas, Madrid, 1986. págs. 121 y ss.

Medina López, C.: "Las alegaciones a los proyectos de informes de los Tribunales de Cuentas: Comunidades Europeas y España", en Tribunal de Cuentas de las Comunidades Europeas y los Tribunales de Cuentas de los países miembros: competencias y relaciones, Tribunal de Cuentas, Madrid, 1986, págs. 277 y ss.

Melendro Arnalz, F.: «El Tribunal de Cuentas de las Comunidades Europeas: Diversos aspectos estructurales y competenciales", en Tribunal de Cuentas de las Comunidades Europeas y los Tribunales de Cuentas de los paises miembros: competencias y relaciones, Tribunal de Cuentas, Madrid, 1986, págs. 287 y ss.

Mendizábal Mendizábal, E.: "Notas sobre el Tribunal de Cuentas de Austria", en Tribunal de Cuentas, Crónica, 1981, Tribunal de Cuentas, Madrid, 1982.

Ming TAO, Y.: "El Tribunal de Cuentas en China», en La función de los Tribunales de Cuentas en la sociedad democrática, Tribunal de Cuentas, Madrid, 1985, págs. 257 y ss.

Morr, J.: «The Legal Basis, organization, planing and Reporting of rigsrevisionen, including proceduresas to Ecfunds", en Tribunal de Cuentas de las Comunidades Europeas y los Tribunales de Cuentas de los países miembros: competencias y relaciones, Tribunal de Cuentas, Madrid, 1986.

Moltó Calvo, M. A.: "El control del Fondo Europeo de desarrollo Regional (FEDER) a través del criterio de eficacian, en Tribunal de Cuentas, Crónica, 1988-1989, Tribunal de Cuentas, Madrid, 1990, págs. 121 y ss.

Morettı, B.: La Corte dei Conti. Origini, ordinamento, funzioni, Milano, 1985. 
Muñoz Álvarez, R.: "La experiencia reformadora de la fiscalización en Canadá", en Tribunal de Cuentas, Crónica, 1981, Madrid, 1982.

NASO, E.: La Costituzione italiana: nell'interpretazione della Corte costituzionale (art. 24-54), Roma, 1971.

Nofuentes García-Montor, M.: "Sistemas institucionales de control en el Derecho", en Tribunal de Cuentas, Crónica, 1981, Madrid, 1982.

Orsoni, G. y Lelong, P.: La Cour des Comptes des Communautes Europeenes, París, 1983.

Palmieri, G. M. y Mónaco, R.: Le corte dei conti delle Communita Europee, Padova, 1983.

PICozzı, L.: La Corte dei Conti in Italia, Torino, 1963.

Pinheiro Farinha, J. de D.: «El Tribunal de Cuentas en Portugal», en La función de los Tribunales de Cuentas, Tribunal de Cuentas, Madrid, 1985, págs. 231 y ss.

- "Posçáo do Tribunal de Contas na estructura do Estado portugues", en Tribunal de Cuentas de las Comunidades Europeas y los Tribunales de Cuentas de los paises miembros: competencias y relaciones, Tribunal de Cuentas, Madrid, 1986, págs. 161 y ss.

Rodrigo Sanz, A. M. y Caso Orgaz, J.: "Apuntes sobre competencias y relaciones de los Tribunales de Cuentas en el marco de la Comunidad Económica European, en Tribunal de Cuentas de las Comunidades Europeas y los Tribunales de Cuentas de los países miembros: competencias y relaciones, Tribunal de Cuentas, Madrid, 1986, págs. 301 y ss.

SCHULZE, H.: Die rolle des rechnungshofs wahrend der vorlaufigen haushaltsfuhrung einer regierung ohne Parlamentsmehrheit, Berlín 1987.

Selbach, J.: «El Tribunal de Cuentas de la República Federal Alemana», en Tribunal de Cuentas, Crónica, 1981, Madrid, 1982.

Sepe, O.: «Algunos aspectos del control del Tribunal de Cuentas italiano sobre los organismos subvencionados por el Estado", R.A.P., no 21, (septiembre-diciembre, 1956), págs. 503 y ss.

Subirats, J.: "El control externo en la Europa Comunitaria», en Tribunal de Cuentas, Crónica, 1988-1989, Tribunal de Cuentas, Madrid, 1990, págs. 103 y ss. 
Themelis, N.: «El Tribunal de Cuentas en Grecia», en La función de los Tribunales de Cuentas en la sociedad democrática, Tribunal de Cuentas, Madrid, 1985, págs. 245 y ss.

- «Rapport between the Greek Court of Audit and the European Communities", en Tribunal de Cuentas de las Comunidades Europeas y los Tribunales de Cuentas de los países miembros: competencias y relaciones, Tribunal de Cuentas, Madrid, 1986, págs. 105 y ss.

THILL, J.: «Les attributions de la Chambre des Comptes du Grand-Duché de Luxembourg et ses relations avec la Cour des Comptes Européenne", en Tribunal de Cuentas de las Comunidades Europeas y los Tribunales de Cuentas de los países miembros: competencias y relaciones, Tribunal de Cuentas, Madrid, 1986, págs. 153 y ss.

V.AA.: Jurisprudence, 1895-1974, Cour de Comptes, Centre National de la Recherche Scientifique, París, 1978-1979.

WITtrock, K.: «El Tribunal de Cuentas en la República Federal de Alemania", en La función de los Tribunales de Cuentas en la sociedad democrática, Tribunal de Cuentas, Madrid, 1985, págs. 239 y ss. 